JURNAL KETAHANAN NASIONAL

Vol. 26, No. 2, Agustus 2020, Hal 229-248

DOI:http://dx.doi.org/ 10.22146/jkn.56926

ISSN:0853-9340(Print), ISSN:2527-9688(Online)

Online sejak 28 Desember 2015 di :http://jurnal.ugm.ac.id/JKN

VOLUME 26

No. 2, Agustus 2020

Halaman 229-248

\title{
Pengembangan Bahan Ajar PPKn Berbasis Kearifan Lokal Guna Meningkatkan Ketahanan Budaya Melalui Pemahaman Konsep Keberagaman
}

\author{
Ridwan Santoso \\ Universitas Negeri Yogyakarta, Indonesia \\ email: ridwansantosopkn@gmail.com \\ Wuri Wuryandani \\ Universitas Negeri Yogyakarta, Indonesia \\ email: wuriwuryandani@uny.ac.id
}

Dikirim:15-06-2020; Direvisi:10-08-2020; Diterima:28-08-2020

\begin{abstract}
This study aimed to produced Civic Education teaching materials based on local wisdom that were appropriate for enhancing the resilience of culture through increasing of the conceptual understanding of the cultural diversity.

This type of study was research and development following ADDIE procedures. The research data were obtained from the needs analysis, expert validation, product implementation in the first field trial (one-to-one trial) and the second field trial (small-group trial) at SMP Negeri 1 Yogyakarta, SMP Negeri 1 Depok, and SMP Muhammadiyah Pakem. This research was carried out until the development stage with research subjects consisting of 3 teachers of Civic Education and 12 students. The research subjects were determined using a purposive technique with consideration from the Civic Education teacher at school.

The results of data analysis proved that Civic Education teaching materials based on local wisdom were very feasible to be used in the learning process in the classroom. The results of this research and development could be the basis of further research and development to developed innovative teaching materials that were appropriate to be used to increased the success of the learning process.
\end{abstract}

Keywords: Development; Teaching Materials; Local Wisdom; Cultural Resilience; Concept Understanding.

\begin{abstract}
ABSTRAK
Penelitian ini bertujuan menghasilkan bahan ajar PPKn berbasis kearifan lokal yang layak untuk meningkatkan ketahanan budaya melalui peningkatan pemahaman konsep keberagaman budaya.

Jenis penelitian ini merupakan penelitian dan pengembangan dengan mengikuti prosedur research and development ADDIE (Analysis, Design, Development, Implementation, and Evaluation). Data penelitian diperoleh dari hasil analisis kebutuhan, validasi ahli, implementasi produk pada uji coba lapangan pertama (one-to-one trial) dan uji coba lapangan kedua (small-group trial) di SMP Negeri 1 Yogyakarta, SMP Negeri 1 Depok, dan SMP Muhammadiyah Pakem. Penelitian ini dilakukan sampai tahap development dengan subjek penelitian terdiri dari 3 guru mata pelajaran PPKn dan 12 peserta didik. Subjek penelitian ditentukan menggunakan teknik purposive dengan pertimbangan dari guru PPKn di sekolah.
\end{abstract}


Hasil analisis data membuktikan produk bahan ajar PPKn berbasis kearifan lokal sangat layak untuk digunakan dalam proses pembelajaran di kelas. Hasil penelitian dan pengembangan ini dapat menjadi dasar penelitian dan pengembangan selanjutnya untuk mengembangkan bahan ajar inovatif yang layak digunakan untuk meningkatkan keberhasilan proses pembelajaran.

Keywords: Pengembangan; Bahan Ajar; Kearifan Lokal; Ketahanan Budaya; Pemahaman Konsep.

\section{PENGANTAR}

Pendidikan merupakan unsur utama yang harus dipersiapkan guna pembangunan sumber daya manusia di suatu negara. Hasil penelitian Sulisworo (2016) membuktikan peran penting dari pendidikan terhadap kualitas sumber daya manusia suatu negara untuk bersaing dengan bangsa lain. Hasil penelitian tersebut menjadi salah satu dasar pentingnya memfasilitasi pembelajaran di sekolah dengan sarana dan prasarana yang memadai guna pembelajaran yang efektif. Hasil temuan Akomolafe dan Adesua (2016) membuktikan peran penting fasilitas pembelajaran di kelas terhadap kinerja akademik dan motivasi belajar peserta didik.

Fasilitas belajar merupakan instrumen pembelajaran yang harus tersedia agar tercipta pembelajaran yang efektif. Oleh karena itu, selain menyediakan media belajar untuk proses pembelajaran, guru dan sumber belajar merupakan fasilitas paling penting penunjang terlaksananya proses pembelajaran. Pentingnya guru dalam proses pembelajaran di sekolah dibuktikan oleh Strom dan Falch (2020) bahwa kualitas pembelajaran di kelas sangat dipengaruhi oleh kualitas guru. Tavakoli dan Baniasad-Azad (2017) menyatakan terdapat tiga faktor yang sangat mempengaruhi pemahaman konsep materi pelajaran pada seorang peserta didik, yaitu keprofesionalan seorang guru, keterampilan dalam mengajar, dan iklim kelas yang tercipta. Bahkan hasil belajar dan prestasi belajar peserta didik sangat ditentukan oleh kualitas dan profesionalisme guru dalam mengajar (Gershenson, 2016).
Guru harus mampu menciptakan proses pembelajaran yang terintegrasi dengan pendidikan di lingkungan sosial masyarakat dan keluarga. Sebagaimana yang dinyatakan Hanushek (2020) bahwa pendidikan di sekolah harus sejalan dengan pendidikan non formal seorang anak dari lingkungan keluarga dan sosial masyarakat atau teman sebaya. Meningkatkan kualitas guru merupakan cara yang paling efektif untuk meningkatkan efektivitas pembelajaran di kelas (Jusuf, 2005). Guru profesional merupakan guru yang mampu menciptakan proses pembelajaran efektif untuk semua peserta didik agar memahami penuh materi pembelajaran yang disampaikan (Fischer dkk., 2018). Pemahaman konsep merupakan salah satu indikator tersampaikan nya informasi atau materi pelajaran kepada peserta didik, seperti yang dinyatakan Rusman (2010: 139) bahwa pemahaman konsep merupakan proses menerima dan memahami dari hasil pembelajaran yang diperoleh. Paham terhadap sesuatu merupakan penguasaan seorang manusia terkait sesuatu melalui pikiran. Oleh karena itu, guru memiliki tuntutan untuk membuat peserta didik paham konsep dari materi ajar dalam proses pembelajaran.

Hasil penelitian Crosby, Laird, dan Younie, (2019) membuktikan bahwa penggunaan sumber belajar memiliki peran besar untuk memberikan pemahaman materi yang diajarkan kepada peserta didik. Sumber belajar sangat mendukung terlaksananya proses pembelajaran yang efektif (Zhang 
dan Sun, 2017). Oleh karena itu, guru harus dapat mengembangkan dan berinovasi terhadap sumber belajar yang digunakan untuk menunjang keberhasilan proses pembelajaran yang mampu memberikan pemahaman konsep kepada peserta didik.

Pentingnya pendidikan terhadap perkembangan suatu negara dibuktikan oleh Hanushek dan Woessmann (2020) bahwa kualitas pendidikan suatu negara mempengaruhi pertumbuhan perekonomian. Peran yang sangat besar dari pendidikan menjadi dasar pentingnya menunjang keberhasilan proses pendidikan. Hal tersebut terbukti dari data yang dirilis oleh Badan Pusat Statistik (BPS), OECD, dan UNDP. Berdasarkan rilis data Badan Pusat Statistik (BPS) Indonesia pada tahun 2017, angka partisipasi murni (APM) pendidikan Indonesia pada tingkat SMP termasuk anak laki-laki dan perempuan baru berjumlah 78,40\% angka partisipasi murni anak Indonesia, yang artinya masih ada $21,60 \%$ anak Indonesia umur sekolah SMP yang tidak bersekolah. Hal itu sejalan dengan rilis data Programme For International Students Assessment (PISA) tahun 2018 bahwa tingkat minat baca peserta didik di Indonesia masih tergolong rendah jika dibandingkan dengan tingkat minat baca negara- lain yang termasuk Responden. Indonesia berada pada urutan 72 dari total 79 negara yang menjadi Responden (OECD, 2018).

Dua rilis data tersebut terbukti sejalan dengan tingkat sumber daya manusia Indonesia. Berdasarkan peringkat sumber daya manusia Indonesia dalam Human Development Index (HDI) atau sumber daya manusia menurut United Nation Development Programme (UNDP) tahun 2018, Indonesia berada pada peringkat 116 dari total 189 negara yang menjadi sampel penelitian (UNDP, 2018). Hal itu membuktikan bahwa faktor pendidikan memiliki peran yang besar terhadap tingkat kualitas sumber daya suatu bangsa. Oleh karena itu, perlu upaya yang nyata untuk memfasilitasi proses pendidikan Indonesia dalam usaha memperbaiki kualitas sumber daya manusia Indonesia.

Viswanath, Kusuma, dan Gupta (2012) menyatakan pendidikan modern merupakan pendidikan yang identik dengan perkembangan pendidikan menggunakan teknologi IT. Tujuannya untuk memfasilitasi proses pembelajaran agar lebih efektif dan efisien. Hasil penelitian Davey, Elliott, dan Bora (2019) dan Shaikh (2019) membuktikan peran positif dari penggunaan teknologi IT untuk menyelesaikan masalah keterbatasan waktu, tempat, dan finansial pelaksanaan pembelajaran. Negara Indonesia menaruh begitu besar harapan kepada dunia pendidikan, dengan begitu banyaknya kebijakan bahkan dengan mengganti dan merevisi kurikulum pendidikan di Indonesia.

Penggunaan Kurikulum 2013 merupakan perbaikan orientasi pendidikan di Indonesia kepada berbasis pengembangan karakter dan kompetensi. Hal itu sangat diharapkan dapat membentuk generasi muda atau warga negara muda yang bermartabat agar bangsa Indonesia memiliki nilai lebih dibandingkan dengan bangsa lain (Mulyasa, 2013: 7). Orientasi pemberlakuan kurikulum 2013 memberikan pengertian bahwa pembelajaran di dalam cakupan kurikulum 2013 tidak lagi hanya berfokus terhadap perkembangan kognitif, tetapi lebih kepada pengembangan dan penanaman sikap serta keterampilan yang diharapkan dapat memberi bekal yang cukup pada seluruh peserta didik dengan menggunakan pola-pola pembelajaran 
berbasis lingkungan sosial budaya. Proses pembelajaran yang demikian tentu dapat berfungsi sebagai langkah preventif dari sekolah untuk menjaga kelestarian kekayaan keberagaman budaya yang dimiliki Indonesia.

Terkikis nya kebudayaan lokal merupakan masalah nyata yang sedang dihadapi Indonesia. Globalisasi melalui perkembangan teknologi digital merupakan penyebab utama terjadinya akulturasi dan asimilasi kebudayaan di Indonesia. Oleh karena itu, perlunya sebuah solusi dalam proses pembelajaran yang mampu menanamkan rasa cinta dan kepemilikan nilai-nilai kekayaan keberagaman budaya lokal daerah kepada setiap peserta didik. Terlebih dengan menguat nya masalah identitas kebangsaan di Indonesia yang ditandai dengan terkikis nya nilai-nilai budaya lokal di lingkungan sosial generasi muda.

Pemerintah memang telah melakukan langkah preventif dengan memberlakukan kebijakan proses pembelajaran di sekolah yang diwajibkan terdapat mata pelajaran muatan lokal. Namun, dalam proses perkembangan di era globalisasi yang sangat pesat, bergantung kepada satu mata pelajaran tidak cukup mampu mempertahankan eksistensi nilainilai kebudayaan lokal daerah dikalangan peserta didik. Terlebih jika menganalisis orientasi pemberlakuan kurikulum 2013 yang berorientasi kepada pembentukan karakter peserta didik. Maka dari itu, setiap mata pelajaran mempunyai peran untuk menanamkan karakter cinta tanah air yang di dalamnya termasuk mencintai nilai kebudayaan lokal.

$$
\text { Pendidikan Pancasila dan }
$$
Kewarganegaraan merupakan salah satu mata pelajaran utama yang diharapkan mampu membentuk sikap dan karakter setiap peserta didik di samping pembelajaran pendidikan agama. Oleh karena itu, dalam usaha membentuk karakter rasa cinta tanah air, sumber belajar yang inovatif dengan basis kearifan lokal merupakan suatu langkah penting guna menunjang penguatan ketahanan budaya lokal di tengah arus globalisasi. Hal itu dikarenakan, sumber belajar dengan basis kearifan lokal merupakan inovasi yang bisa dilakukan oleh seluruh guru di sekolah termasuk pada mata pelajaran Pendidikan Pancasila dan Kewarganegaraan.

Bangsa Indonesia memiliki kekayaan budaya yang sangat melimpah. Memanfaatkan kekayaan budaya lokal Indonesia untuk dijadikan sebagai bahan ajar merupakan suatu peluang yang harus mampu dimanfaatkan oleh seluruh praktisi pendidikan di Indonesia guna menunjang proses pembelajaran dalam kurikulum 2013. Melalui usaha mengembangkan bahan ajar dengan basis nilai lokal diharapkan efektif meningkatkan efektivitas pembelajaran peserta didik berupa peningkatan pemahaman konsep keberagaman budaya sekaligus berdampak pada usaha mempertahankan nilai-nilai kebudayaan lokal di kalangan generasi muda.

Pemanfaatan nilai-nilai lokal dalam pengembangan bahan ajar mata pelajaran Pendidikan Pancasila dan Kewarganegaraan tentu harus dilakukan di materi ajar yang sesuai. Pengembangan bahan ajar PPKn dengan basis kearifan lokal harus dilakukan berdasarkan hasil analisis kebutuhan guna mengetahui kebutuhan dan materi yang tepat dan sesuai dengan tema penelitian dan pengembangan yang dilakukan. Materi keberagaman pada jenjang SMP kelas VII khususnya pada semester 2 merupakan materi ajar yang sesuai dengan tema pengembangan bahan ajar. Materi keberagaman dalam buku 
ajar dari pemerintah memiliki keterbatasan nilai-nilai budaya yang luas untuk digunakan sebagai contoh dalam buku ajar. Hal itu dikarenakan, buku ajar dari pemerintah, tentunya harus dapat berlaku dan digunakan secara nasional di setiap daerah yang berarti tidak hanya berorientasi kepada salah satu budaya lokal suatu daerah.

Yudha dkk (2019) membuktikan pembelajaran kontekstual efektif meningkatkan pemahaman konsep pada peserta didik. Pembelajaran kontekstual merupakan bentuk pelaksanaan pembelajaran yang mengelaborasi materi ajar dengan kondisi di lingkungan sekitar. Melalui pembelajaran yang kontekstual peserta didik akan mendapatkan pemahaman konsep lebih kuat jika dibandingkan dengan proses pembelajaran yang hanya berdasarkan pengertian atau contoh-contoh umum (Yeni, Syarifuddin, dan Ahmad, 2019). Hasil penelitian Satriani, Emilia, dan Gunawan (2012) membuktikan bahwa pembelajaran kontekstual mendorong peserta didik untuk mampu menyelesaikan masalah, meningkatkan motivasi belajar, dan merangkum untuk mencerminkan materi pelajaran yang dipelajari.

Pemahaman peserta didik terbukti bertahan lebih lama ketika materi yang dipelajari relevan dengan konteks nyata (Nasreen, Janjua, dan Malik, 2018). Temuan Nilasari, Djatmika, dan Santoso (2016) membuktikan pengaruh yang signifikan dari penggunaan sumber belajar kontekstual terhadap hasil belajar seorang peserta didik. Pembelajaran kontekstual mampu memberikan pengalaman belajar lebih pada peserta didik dari hasil proses pembelajaran (Perwitasari dan Wahjoedi, 2018). Karena melalui sumber belajar yang kontekstual peserta didik dapat mengetahui contoh-contoh nyata di lingkungan sekitar. Maka dari itu, peserta didik dapat mengaitkan materi pelajaran dengan kondisi nyata.

Efektifnya pembelajaran kontekstual harus mampu dimanfaatkan guru untuk meningkatkan efektivitas pembelajaran di kelas. Namun, dari hasil penelitian analisis kebutuhan yang telah dilakukan di SMP Negeri 1 Yogyakarta, SMP Negeri 4 Depok, dan SMP Muhammadiyah Pakem Yogyakarta memberikan informasi bahwa bahan ajar PPKn dengan basis kearifan lokal belum ada di sekolah. Bahkan secara spesifik, pada materi keberagaman di Indonesia khususnya pada SMP kelas VII belum tersedia untuk bisa dimanfaatkan guru dan peserta didik.

Muatan umum pada buku ajar dari pemerintah menjadi salah satu alasan perlunya pengembangan bahan ajar PPKn dengan memanfaatkan nilai kearifan lokal yang bisa dan layak untuk dimanfaatkan peserta didik dan pendidik di daerah tersebut. Hasil penelitian Dewi dkk (2014) membuktikan bahwa penggunaan nilai lokal dalam proses belajar terbukti efektif peningkatan hasil belajar. Begitupun hasil penelitian Pangalila dkk (2018) yang membuktikan bahwa dengan memasukan nilai budaya lokal ke dalam proses pembelajaran, memiliki pengaruh signifikan terhadap peningkatan sikap toleransi antar peserta didik. Hasil penelitian tersebut mendukung dilakukannya pengembangan sumber bajar PPKn dengan basis kearifan lokal guna mempertahankan kebudayaan lokal melalui peningkatan pemahaman konsep keberagaman pada peserta didik sebagai generasi muda. Bahkan sekaligus terbukti dapat meningkatkan toleransi antar peserta didik sebagaimana hasil penelitian sebelumnya.

Bahan ajar berbasis kearifan lokal merupakan bahan ajar yang dikembangkan 
dengan memanfaatkan kekayaan budaya lokal dengan tujuan dapat menjadi sumber belajar yang layak guna memberikan pengalaman belajar pada setiap peserta didik. Amanat kurikulum 2013 mengharuskan pembelajaran di sekolah bisa memberikan pengalaman belajar. Baka, Laksana, dan Dhiu (2019) membuktikan bahwa belajar melalui bahan ajar dengan konten budaya memberikan pengalaman belajar yang lebih sehingga peserta didik merasa memiliki nilai-nilai budaya tersebut. Upaya memperkuat ketahanan budaya di Indonesia, guru memerlukan bahan ajar kontekstual untuk memberikan pengalaman belajar pada peserta didik. Pengembangan bahan ajar PPKn berbasis kearifan lokal merupakan pengembangan bahan ajar yang kontekstual yang bertujuan menciptakan sumber belajar yang layak untuk dipergunakan peserta didik dalam upaya meningkatkan ketahanan budaya lokal daerah melalui peningkatan pemahaman konsep keberagaman budaya siswa dan pengalaman belajar siswa dari proses belajar di sekolah. Namun, produk yang dikembangkan berupa bahan ajar PPKn perlu dibuktikan kelayakannya. Oleh karena itu, bagaimanakah kelayakan produk penelitian dan pengembangan guna meningkatkan dampak pembelajaran berupa ketahanan budaya lokal daerah melalui peningkatan pemahaman konsep keberagaman budaya peserta didik.

Hasil analisis kebutuhan membuktikan bahwa pembelajaran di sekolah masih sangat bergantung pada buku ajar dari pemerintah. Padahal buku ajar dari pemerintah memiliki keterbatasan cakupan yang luas guna pemberlakuan secara nasional. Kondisi tersebut sesuai dengan fakta bahwa belum ada bahan ajar hasil pengembangan dengan basis kearifan lokal Yogyakarta yang dapat dimanfaatkan pendidik dan peserta didik untuk menunjang pembelajaran Pendidikan Pancasila dan Kewarganegaraan di sekolah. Temuan tersebut sejalan dengan hasil penelitian Wijianto (2019) bahwa buku di sekolah masih didominasi buku paket. Hal itu sedikit bertolak belakang dengan kondisi kekayaan budaya yang ada di Yogyakarta yang seharusnya dapat dimanfaatkan oleh pendidik serta peserta didik sebagai media belajar atau sumber belajar. Maka dari itu, pengembangan bahan ajar yang dilakukan sangat diperlukan untuk menciptakan bahan ajar PPKn yang layak pada materi keberagaman guna meningkatkan ketahanan budaya lokal Indonesia.

Penelitian ini merupakan jenis penelitian dan pengembangan yang mengikuti desain ADDIE (Analysis, Design, Development, Implementation, and Evaluation) (Branch, 2009). Produk yang dihasilkan dari penelitian dan pengembangan ini merupakan bahan ajar PPKn berbasis kearifan lokal yang layak untuk digunakan pendidik dan peserta didik dalam proses pembelajaran guna mempertahankan kebudayaan lokal daerah di Indonesia. Tahaptahap penelitian dan pengembangan di dalam desain penelitian ADDIE diawali dengan menganalisis kebutuhan produk yang dikembangkan, mendesain produk, menguji kelayakan produk, mengimplementasikan produk, dan mengevaluasi kelayakan produk. Adapun tahapan-tahapan penelitian dan pengembangan pada prosedur ADDIE dari Branch (2009: 2) dapat dilihat pada gambar 1.

Subjek penelitian ini terdiri dari 12 siswa kelas VII SMP Muhammadiyah Pakem, Sleman, dan tiga guru mata pelajaran PPKn di tiga sekolah SMP Negeri 1 Yogyakarta, SMP Negeri 1 Depok, dan SMP Muhammadiyah Pakem. Penentuan subjek penelitian peserta didik menggunakan teknik purposive 


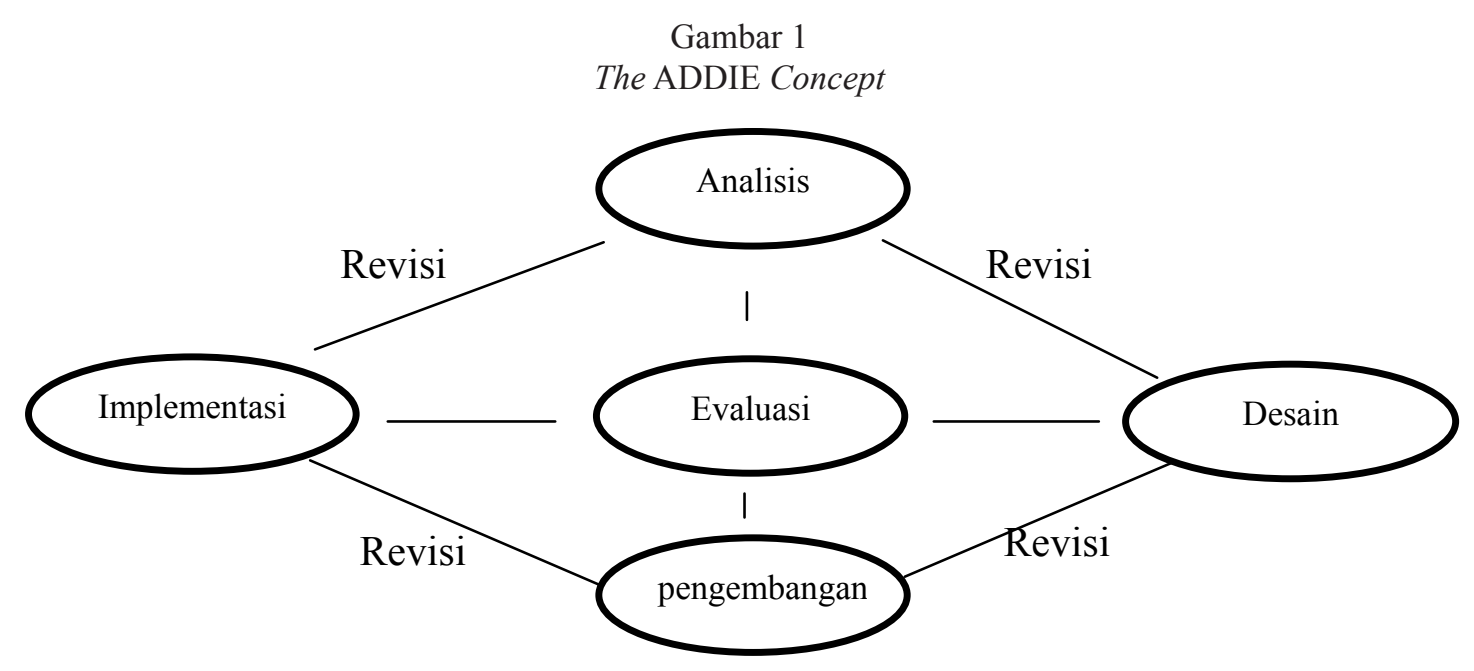

Sumber: Branch, 2009.

dengan pertimbangan dari guru PPKn di SMP Muhammadiyah Pakem. Teknik pengumpulan data penelitian menggunakan teknik wawancara, lembar isian validasi ahli, lembar penilaian siswa, dan lembar penilaian guru. Teknik wawancara yang digunakan merupakan wawancara semi terstruktur guna mengetahui kebutuhan pengembangan bahan ajar PPKn berbasis kearifan lokal di sekolah sebelum pengembangan bahan ajar dilakukan.

Uji kelayakan produk diawali dengan memvalidasi produk penelitian dan pengembangan kepada dosen ahli materi dan ahli media melalui lembar validasi yang didasarkan pada kriteria kelayakan bahan ajar berdasarkan standar bahan ajar dari BNSP. Lembar kuesioner validasi ahli, lembar penilaian kelayakan dari peserta didik, dan lembar penilaian kelayakan dari guru yang digunakan divalidasi oleh dosen ahli instrumen agar tidak menimbulkan ambiguitas dan memperoleh data yang valid. Uji kelayakan produk oleh guru dan peserta didik dilakukan melalui dua tahap yaitu Oneto-one trial dan Small-group trial.

Data penelitian dianalisis dengan (1) menabulasi data hasil validasi produk dari ahli materi, media, penilaian peserta didik, dan penilaian pendidik, (2) menghitung rata-rata hasil penilaian kelayakan yang diperoleh dari penilaian ahli materi, ahli media, pendidik, dan peserta didik, (3) mengkonversikan nilai penilaian ahli, penilaian kelayakan pendidik dan penilaian kelayakan peserta didik ke dalam interval kategori kelayakan bahan ajar. Hasil analisis data dikomparasikan untuk menentukan kelayakan bahan ajar PPKn berbasis kearifan lokal terhadap pemahaman konsep keberagaman budaya. Rumus perhitungan rata-rata hasil penilaian kelayakan menggunakan rumus rata rata yang dapat dilihat pada gambar 2 .

Gambar 2

Rumus Rata-Rata

$$
x=\frac{\sum x}{n}
$$

$$
\begin{array}{ll}
\text { Ket: } & \\
x & =\text { Nilai rata-rata } \\
\sum x & =\text { Total Nilai } \\
\mathrm{n} & =\text { Total pemberi nilai }
\end{array}
$$

Sumber: Sugiyono, 2013: 49. 
Sedangkan interval kategori kelayakan dari produk bahan ajar dapat dilihat pada tabel 1 .

\section{PEMBAHASAN}

Hasil dari penelitian dan pengembangan ini merupakan produk bahan ajar PPKn berbasis kearifan lokal yang bertujuan untuk meningkatkan pemahaman konsep keberagaman budaya peserta didik di kelas VII guna mempertahankan budaya lokal di tengah era globalisasi yang berkembang pesat dan berdampak terhadap terkikis nya nilai lokal daerah di kalangan generasi muda. Pengembangan ini dilakukan untuk menciptakan produk pengembangan bahan ajar PPKn berbasis kearifan lokal yang layak untuk digunakan peserta didik dan pendidik di sekolah.

\section{Analyze}

Hasil dari penelitian dan pengembangan ini merupakan bahan ajar PPKn berbasis kearifan lokal yang dapat dipergunakan peserta didik dan guru secara layak guna meningkatkan pemahaman konsep keberagaman budaya peserta didik kelas VII guna mempertahankan budaya lokal Indonesia. Pengembangan bahan ajar PPKn berbasis kearifan lokal diawali dengan melakukan analisis terhadap kebutuhan bahan ajar yang akan dikembangkan. Hal itu diperuntukkan agar diketahui produk yang dibutuhkan di lapangan.

Proses analisis kebutuhan penelitian dan pengembangan dilaksanakan dengan melalui wawancara dan observasi ke sekolah. Hasil wawancara kepada subjek penelitian guru mata pelajaran Pendidikan Pancasila dan Kewarganegaraan kelas VII di tiga sekolah menyatakan bahwa belum terdapat sumber ajar PPKn yang memanfaatkan nilai lokal yang bisa dipergunakan pendidik ataupun peserta didik di dalam pembelajaran. Pernyataan yang diberikan guru mata pelajaran PPKn tersebut memberikan informasi bahwa produk yang akan dikembangkan belum tersedia di sekolah.

Data hasil wawancara didukung dengan hasil observasi di perpustakaan sekolah yang membuktikan bahwa belum ada bahan ajar atau buku PPKn yang berbasis kearifan lokal daerah di sekolah. Jumlah persentase ketersediaan buku PPKn di sekolah berjumlah $87 \%$ merupakan buku ajar PPKn dari pemerintah dan 13\% lainnya terdiri dari buku bacaan, kamus, dan majalah. Belum terdapatnya sumber ajar PPKn yang berbasis nilai-nilai lokal daerah memberikan informasi bahwa perlunya mengembangkan sumber ajar

Tabel 1

Kriteria Konversi Data Kelayakan Produk

\begin{tabular}{clr}
\hline Nilai & Interval & Kategori. \\
\hline A & $(M i+1,5 * S D)<X \leq(M i+3 * S D)$ & Sangat Layak \\
B & $(M i)<X \leq(M i+1,5 * S D)$ & Layak \\
C & $(M i-1,5 * S D)<X \leq(M i)$ & Kurang Layak \\
D & $(M i-3 * S D)<X \leq(M i-1,5 * S D)$ & Tidak Layak \\
\hline
\end{tabular}

Keterangan:
$M i=$ Rata-rata ideal $=\frac{1}{2}$ (skor maks ideal + skor min ideal $) ; S D=$ Standar Deviasi $=\frac{1}{6}($ skor maks ideal - skor min
ideal $) ; X=$ Nilai Empiris

Sumber: Widoyoko, 2009: 238. ideal); $X=$ Nilai Empiris. 
PPKn yang berbasis nilai-nilai lokal guna mempertahankan nilai kebudayaan lokal. Hal itu dikarenakan, masalah memudarnya nilai budaya lokal di kalangan peserta didik memerlukan upaya penanggulangan yang efektif. Temuan Andayani, Martono, dan Muhamad, (2017) dan Lestari, Armawi, dan Muhamad, (2016) membuktikan bahwa melalui penyadaran, pengkapasitasan, dan pemberian sumber daya dapat berpengaruh terhadap ketahanan sosial budaya suatu daerah. Oleh karena itu, upaya penyadaran, pengkapasitasan, dan pemberian sumber daya kepada seluruh peserta didik melalui produk pengembangan yang dikembangkan diharapkan dapat meningkatkan ketahanan budaya lokal Indonesia.

Hasil penelitian Anikarnisia dan Wilujeng (2020) membuktikan bahwa dibutuhkannya pengintegrasian pembelajaran dengan nilainilai lokal daerah sekitar. Bahkan berdasarkan hasil penelitian Asmah dan Mustaji (2014) membuktikan bahwa penggunaan media yang kontekstual berdasarkan keadaan di lingkungan sekitar lebih efektif terhadap kemampuan motorik siswa. Tujuannya adalah memberikan contoh nyata nilainilai lokal kepada peserta didik. Terlebih berdasarkan temuan Fitiriasari (2019) tanpa adanya partisipasi (upaya melestarikan), maka budaya tidak akan bertahan. Oleh karena itu, berdasarkan hasil wawancara dan observasi pada tahap analyze menjadi dasar bahwa tindakan mengembangkan sumber ajar PPKn berbasis kearifan lokal sangat dibutuhkan guna menunjang upaya mempertahankan budaya lokal Indonesia melalui peningkatan pemahaman konsep dan memberikan pengalaman belajar yang lebih baik kepada setiap peserta didik yang belajar di sekolah.

\section{Design}

Tahap kedua penelitian pengembangan ini merupakan mendesain produk penelitian dan pengembangan. Perencanaan bentuk dan tujuan produk merupakan langkah pertama dalam tahap mendesain produk pengembangan. Produk penelitian dan pengembangan ini disusun dengan ukuran kertas Kuarto (A4) dan disusun sesuai dengan tujuan pembelajaran di silabus kurikulum 2013 dan di Rencana Pelaksanaan Pembelajaran yang berlaku dalam kurikulum 2013 (lihat gambar 3).

Tahap desain merupakan penyusunan produk yang dimulai dari penentuan tema bahan ajar yang didasarkan pada kebutuhan setiap peserta didik pada bahan ajar yang dikembangkan. Tema keberagaman merupakan tema besar yang diperoleh berdasarkan dari analisis kebutuhan pada materi pelajaran yang relevan dengan basis nilai-nilai kearifan lokal. Hal itu dikarenakan, ketahanan sosial budaya terbentuk dari upaya melestarikan dengan menjaga, mengembangkan, dan memanfaatkan potensi kekayaan lokal yang dimiliki (Suradiva, Muhammad, dan Saryani, 2018).

Penentuan tema keberagaman sebagai tema besar dalam penelitian dan pengembangan yang dilakukan dikarenakan perlunya upaya pelestarian dari berbagai macam ragam kekayaan budaya Indonesia. Maka dari itu, produk penelitian dan pengembangan disusun dengan rancangan sub-tema yang terdiri dari pengertian budaya dan keberagaman, jenis keberagaman, faktor penyebab keberagaman, dan alasan pentingnya pemahaman konsep keberagaman dalam proses kehidupan sosial budaya. Empat sub-tema tersebut disusun dalam produk bahan ajar hingga terbentuknya sumber ajar PPKn dengan memanfaatkan nilai lokal yang memenuhi kriteria layak untuk 
Ridwan Santoso, Wuri Wuryandani -- Pengembangan Bahan Ajar PPKn Berbasis Kearifan Lokal Guna

Meningkatkan Ketahanan Budaya Melalui Pemahaman Konsep Keberagaman

Gambar 3

Cover Awal Produk Bahan Ajar

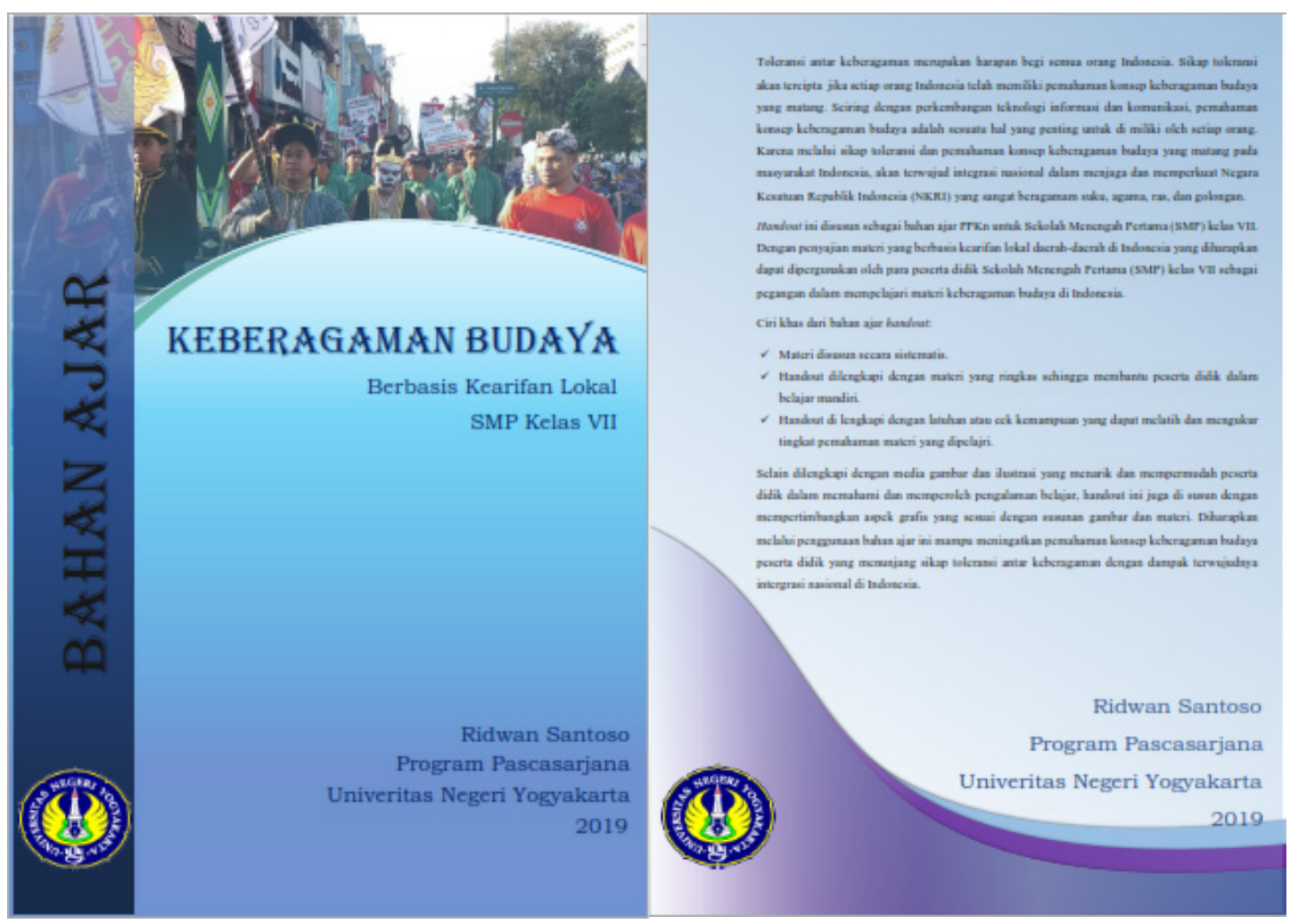

Sumber: Dokumentasi Produk Penelitian dan Pengembangan

dipergunakan peserta didik dan pendidik di dalam proses pembelajaran.

\section{Development}

Berdasarkan produk pengembangan yang telah tersusun berdasarkan kebutuhan dan orientasi pembelajaran dalam silabus kurikulum 2013, maka tahap selanjutnya adalahmemvalidasi produk penelitian dan pengembangan kepada dosen ahli. Langkah memvalidasi produk penelitian dan pengembangan dimulai dengan menyusun dan memvalidasi instrumen penelitian berupa lembar validasi kepada ahli, lembar penilaian peserta didik, dan guru.

Hasil validasi ahli instrumen membuktikan bahwa instrumen penelitian yang akan digunakan berkategori sangat layak jika dipergunakan untuk penelitian dan pengembangan. Skor empiris kelayakan instrumen penelitian yang diperoleh dari hasil validasi ahli instrumen (X) adalah 40. Skor tersebut berarti berada pada interval kelayakan $39<\mathrm{X} \leq 48$ berada pada interval sangat layak. Hasil validasi ahli instrumen menjadi dasar dilanjutkannya penelitian dan pengembangan ke tahap validasi yang dilakukan ahli media dan materi. Skor kelayakan dari ahli instrumen dapat ditunjukkan pada tabel 2.

Tabel 2

Validasi Ahli Instrumen

\begin{tabular}{clc}
\hline No & Penilaian & Skor \\
\hline 1 & Tata Bahasa & 10 \\
2 & Isi- Kesesuaian teknik & 10 \\
3 & Isi-kelengkapan instrumen & 7 \\
4 & Isi-ketepatan identitas & 13 \\
\hline \multicolumn{2}{c}{ Total } & 40 \\
\hline
\end{tabular}

Sumber: Hasil Pengolahan Data 
Sedangkan interval nilai kelayakan instrumen penelitian yang dilakukan dapat dilihat pada tabel 3 .

Tabel 3

Kriteria Kelayakan Instrumen Penelitian

\begin{tabular}{clr}
\hline Nilai & Skor & Kategori \\
\hline A & $39<\mathrm{X} \leq 48$ & Sangat Layak \\
B & $30<X \leq 39$ & Layak \\
C & $21<X \leq 30$ & Kurang Layak \\
D & $12<X \leq 21$ & Tidak Layak \\
\hline
\end{tabular}

Sumber: Hasil Pengolahan Data

Berdasarkan hasil validasi instrumen penelitian, maka validasi produk dapat dilakukan dengan menggunakan instrumen yang telah valid. Produk penelitian dan pengembangan yang memanfaatkan nilai lokal di nilai oleh seorang ahli materi dan ahli media guna memperoleh kriteria kelayakan pada aspek materi dan media. Hasil validasi ahli materi pada produk penelitian dan pengembangan mendapatkan skor skor empiris (X) adalah 70. Skor tersebut membuktikan bahwa sumber ajar PPKn hasil pengembangan berada pada interval $65<\mathrm{X} \leq 80$ yang berarti berkategori sangat layak untuk dipergunakan di dalam pembelajaran. Skor kelayakan dari dosen ahli materi dapat ditunjukkan pada tabel 4.

Tabel 4

Hasil Penilaian Kelayakan Ahli Materi

\begin{tabular}{clc}
\hline No. & Aspek Penilaian & Skor \\
\hline 1 & Bahasa & 20 \\
2 & Isi/Materi & 30 \\
3 & Penyajian & 20 \\
\hline & Total & 70 \\
& Sumber: Hasil Pengolahan Data
\end{tabular}

Sedangkan interval kelayakan materi bahan ajar disajikan pada tabel 5 .

Nilai kelayakan "sangat layak" diperoleh setelah melalui proses beberapa kali revisi
Tabel 5

Kriteria Kelayakan Materi Bahan Ajar

\begin{tabular}{clr}
\hline Nilai & Interval & Kategori \\
\hline A & $65<\mathrm{X} \leq 80$ & Sangat Layak \\
B & $50<\mathrm{X} \leq 65$ & Layak \\
C & $35<\mathrm{X} \leq 50$ & Kurang layak \\
D & $20<\mathrm{X} \leq 35$ & Tidak layak \\
\hline \multicolumn{2}{c}{ Sumber: Hasil Pengolahan Data }
\end{tabular}

produk penelitian dan pengembangan pada aspek materi. Ahli materi menyarankan untuk lebih memperjelas contoh-contoh nyata dari nilai kearifan lokal sebagai basis dari produk penelitian dan pengembangan. Hal itu dikarenakan, melalui peran yang nyata dari pemuda dalam melestarikan budaya lokal berfungsi efektif meningkatkan ketahanan budaya (Mantri, 2014). Hasil revisi produk sesuai saran dari ahli materi disajikan pada gambar 4 .

Nilai Kelayakan bahan ajar yang diperoleh pada lingkup materi dilanjutkan ke tahap uji kelayakan produk pada aspek media kepada ahli media. Hasil penilaian yang dilakukan oleh ahli media didapatkan nilai empiris kelayakan produk pada aspek media (X) adalah 77. Skor tersebut membuktikan bahwa aspek media berada pada interval kelayakan $65<\mathrm{X} \leq 80$ yang berada pada kategori sangat layak guna dipergunakan di dalam proses belajar mengajar. Nilai kelayakan dari dosen ahli media dapat ditunjukkan pada tabel 6 .

Tabel 6

Data Penilaian Ahli Media

\begin{tabular}{llr}
\hline No & Aspek Penilaian & Skor \\
\hline 1 & Tampilan & 36 \\
2 & Bahasa dan ilustrasi & 41 \\
\hline Total & & 77 \\
\hline & Sumber: Hasil Pengolahan Data.
\end{tabular}

Sedangkan interval kelayakan media bahan ajar disajikan pada tabel 7 . 
Ridwan Santoso, Wuri Wuryandani -- Pengembangan Bahan Ajar PPKn Berbasis Kearifan Lokal Guna

Meningkatkan Ketahanan Budaya Melalui Pemahaman Konsep Keberagaman

Gambar 4

Revisi Produk Dari Ahli Materi

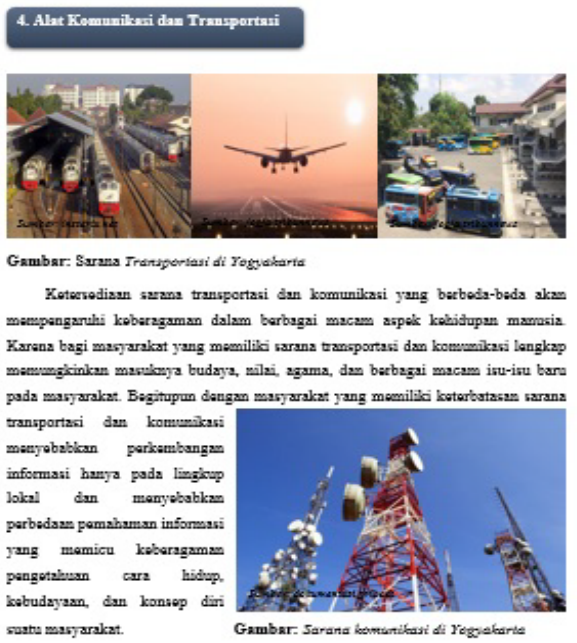

Bahan Ajar PPKn bertasis Kourifan Lokal SMP kolas VII

Sebelum

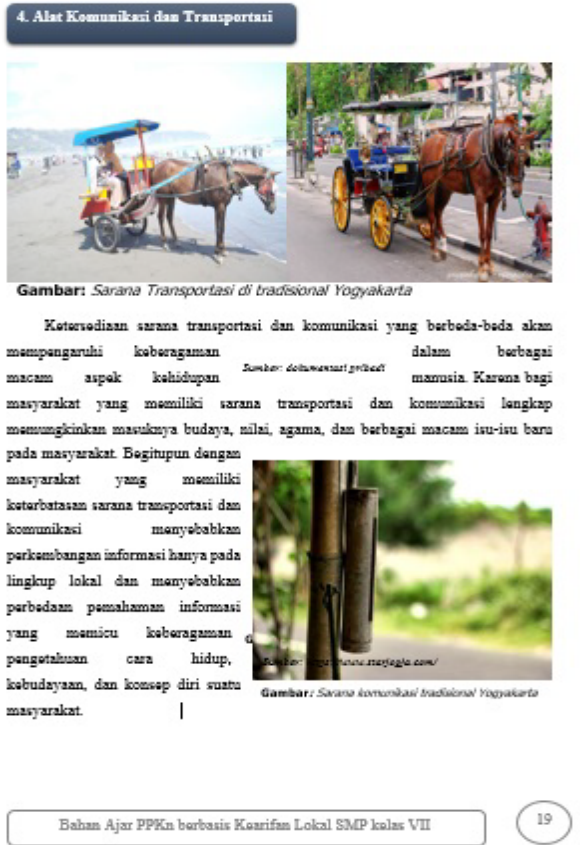

Sesudah

Sumber: Dokumentasi Produk Penelitian dan Pengembangan

Tabel 7

Kriteria Kelayakan Media Bahan Ajar

\begin{tabular}{clr}
\hline Nilai & Nilai & Kategori \\
\hline A & $65<\mathrm{X} \leq 80$ & Sangat Layak \\
B & $50<\mathrm{X} \leq 65$ & Layak \\
C & $35<\mathrm{X} \leq 50$ & Kurang layak \\
D & $20<\mathrm{X} \leq 35$ & Tidak layak \\
\hline \multicolumn{3}{c}{ Sumber: Hasil Olah Data Penelitian. }
\end{tabular}

Berdasarkan hasil penilaian ahli media membuktikan produk penelitian dan pengembangan sangat layak untuk digunakan. Skor kelayakan aspek media diperoleh setelah melakukan beberapa kali perbaikan produk sesuai masukan ahli media. Perbaikan tata bahasa, memperjelas ilustrasi gambar di sampul depan dan sampul belakang, merubah warna background produk, dan memperbaiki tatanan peta konsep. Oleh karena itu, di waktu pelaksanaan validasi ahli, produk pengembangan dilakukan perbaikan sesuai arahan dari ahli media dan materi seperti penggunaan bahasa yang lebih komunikatif serta sesuai dengan PUEBI. Hasil revisi produk pengembangan yang terkait dengan sampul produk bahan ajar disajikan pada gambar 5.

Sedangkan hasil revisi produk pengembangan yang terkait dengan peta konsep, background, dan header, footer ditunjukkan pada gambar 6 .

\section{One-To-One Trial}

Hasil penilaian dari ahli materi dan media menjadi alasan dilakukannya implementasi produk ke tahap uji coba lapangan pertama (One-to-one trial) dalam proses pembelajaran di sekolah. Hasil pengujian pertama (One-toOne Trial) diperoleh hasil bahwa siswa dapat memahami materi ajar dengan menggunakan 
Gambar 5

Sampul Produk Bahan Ajar Hasil Revisi Ahli Media
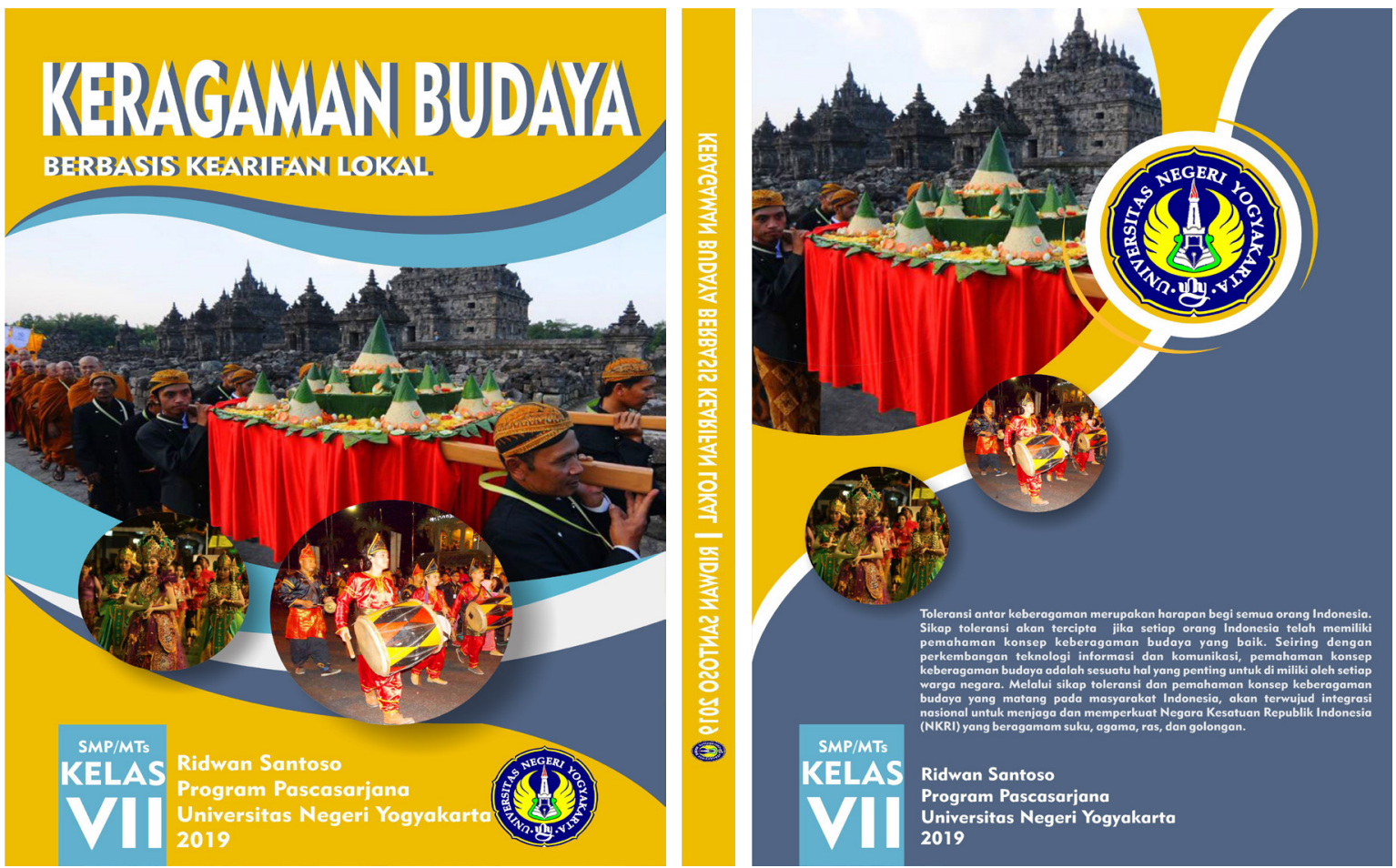

Sumber: Dokumentasi Produk Penelitian dan Pengembangan

Gambar 6

Sebelum

Revisi Peta Konsep, Background, dan Header, Footer

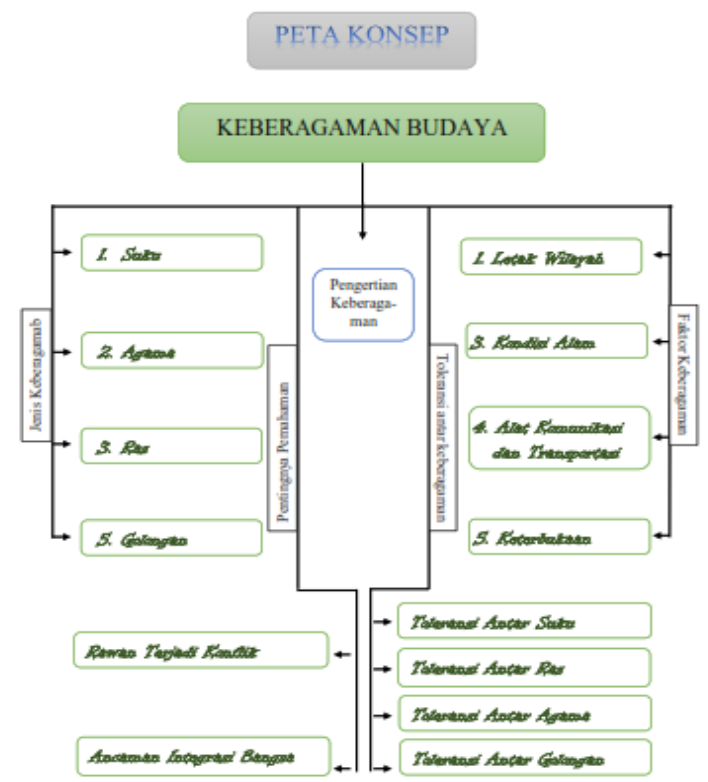

Behan Ajar PPKn berbasis Kerrifan Lokal SMP kelas VII

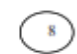

Sesudah

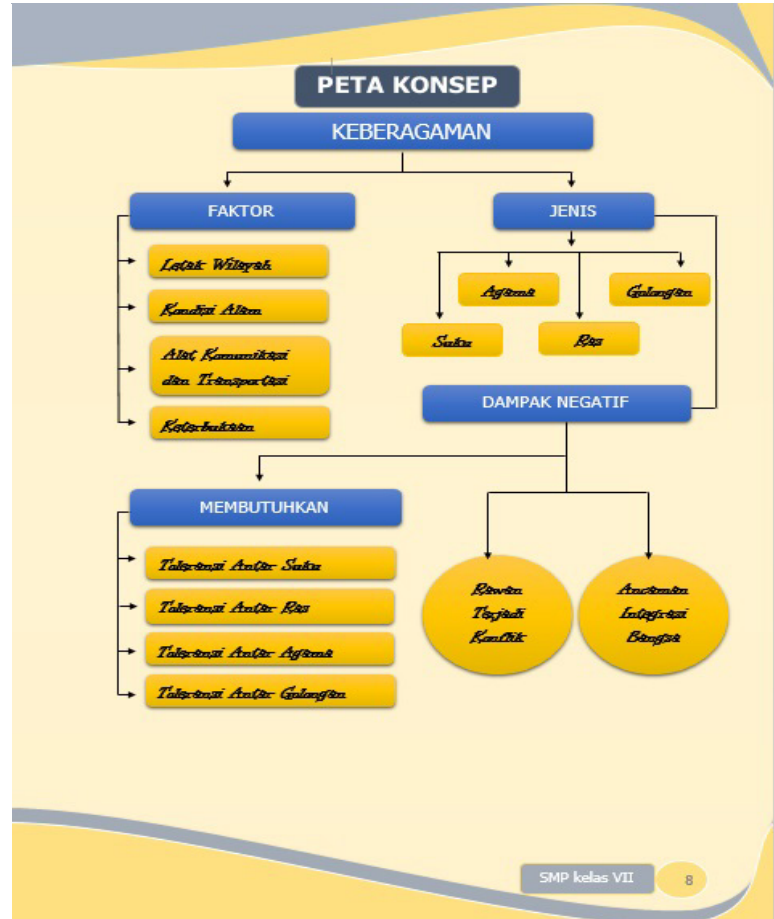

Sumber: Dokumentasi Produk Penelitian dan Pengembangan 
produk penelitian dan pengembangan pada materi keberagaman berupa bahan ajar PPKn berbasis kearifan lokal. Skor empiris penilaian peserta didik (X) pada responden 1 adalah 27 dan responden 2 adalah 28. Hasil tersebut membuktikan bahwa produk yang dikembangkan berupa bahan ajar PPKn berbasis kearifan lokal berada pada kategori (B) layak untuk digunakan karena pada interval $25<\mathrm{X} \leq 32,5$. Skor kelayakan dari pengujian produk di tahap One-to-One Trial pada peserta didik disajikan pada tabel 8 .

Tabel 8

Data Penelitian One-to-One Trial

\begin{tabular}{cccccc}
\hline No & Responden & Skor & $\begin{array}{c}\text { Rata- } \\
\text { rata }\end{array}$ & Nilai & Kategori \\
\hline 1 & Responden-1 & 27 & 27,5 & B & Layak \\
2 & Responden-2 & 28 & & & \\
\hline
\end{tabular}

Sumber: Hasil Pengolahan Data

Sedangkan interval kelayakan produk pada One-to-One Trial respons peserta didik ditunjukkan pada tabel 9.

Tabel 9

Interval Kelayakan Produk Pada One-to-One Trial Respons Peserta Didik

\begin{tabular}{clr}
\hline $\begin{array}{c}\text { Interval Respons } \\
\text { Siswa }\end{array}$ & $\begin{array}{c}\text { Interval } \\
\text { Respons Siswa }\end{array}$ & \multicolumn{1}{c}{ Kategori } \\
\hline A & $32,5<\mathrm{X} \leq 40$ & Sangat Layak \\
B & $25<\mathrm{X} \leq 32,5$ & Layak \\
C & $17,5<\mathrm{X} \leq 25$ & Kurang layak \\
D & $10<\mathrm{X} \leq 17$ & Tidak layak \\
\hline
\end{tabular}

Sumber: Hasil pengolahan data

Pada tahap one-to-one trial juga diberikan lembar penilaian kepada guru mata pelajaran PPKn sebagai pengguna produk penelitian dan pengembangan agar diperoleh masukan dan penilaian terhadap produk yang dikembangkan berupa bahan ajar PPKn berbasis kearifan lokal. Hasil penilaian guru diperoleh skor empiris (X) sebesar 45 yang membuktikan bahwa bahan ajar berada pada interval kelayakan (B) layak untuk dipergunakan dalam kegiatan pembelajaran karena berada pada interval $42,5<\mathrm{X} \leq 55,25$. Skor kelayakan dari penilaian guru mata pelajaran di tahap One-to-One Trial disajikan pada tabel 10 .

Tabel 10

Data Penelitian One-to-One Trial Penilaian Guru

\begin{tabular}{ccccr}
\hline No & Responden & Skor & Nilai & Kategori \\
\hline 1 & Guru mata pelajaran & 45 & B & Layak \\
\hline
\end{tabular}

Sumber: Hasil Pengolahan Data

Sedangkan interval penilaian guru pada pengujian kelayakan produk tahap pertama (one-to-one trial) disajikan pada tabel 11.

Tabel 11

Interval Penilaian Guru

\begin{tabular}{clr}
\hline Nilai & Interval Respons Guru & Kategori \\
\hline A & $55,25<\mathrm{X} \leq 68$ & Sangat Layak \\
B & $42,5<\mathrm{X} \leq 55,25$ & Layak \\
C & $29,75<\mathrm{X} \leq 42,5$ & Kurang layak \\
D & $17<\mathrm{X} \leq 29,75$ & Tidak layak \\
\hline \multicolumn{3}{c}{ Sumber: Hasil Pengolahan Data }
\end{tabular}

Hasil tahap uji coba tahap pertama (Oneto-One Trial) diperoleh masukan dari peserta didik dan guru untuk memperjelas contoh gambar pada setiap materi belajar agar lebih mudah dipahami poin-poin materi yang dapat diilustrasikan. Oleh karena itu, dilakukan beberapa revisi pada aspek ilustrasi gambar di dalam produk penelitian dan pengembangan. Hasil revisi produk di pengujian lapangan pertama (One-to-One Trial) disajikan pada gambar 7 .

\section{Small-Group Trial}

Hasil pengujian tahap pertama menjadi dasar dilakukannya implementasi produk pada tahap pengujian kedua dengan skala yang lebih besar (Small-Group Trial). Hasil uji 
Gambar 7

Revisi hasil One-to-One Trial

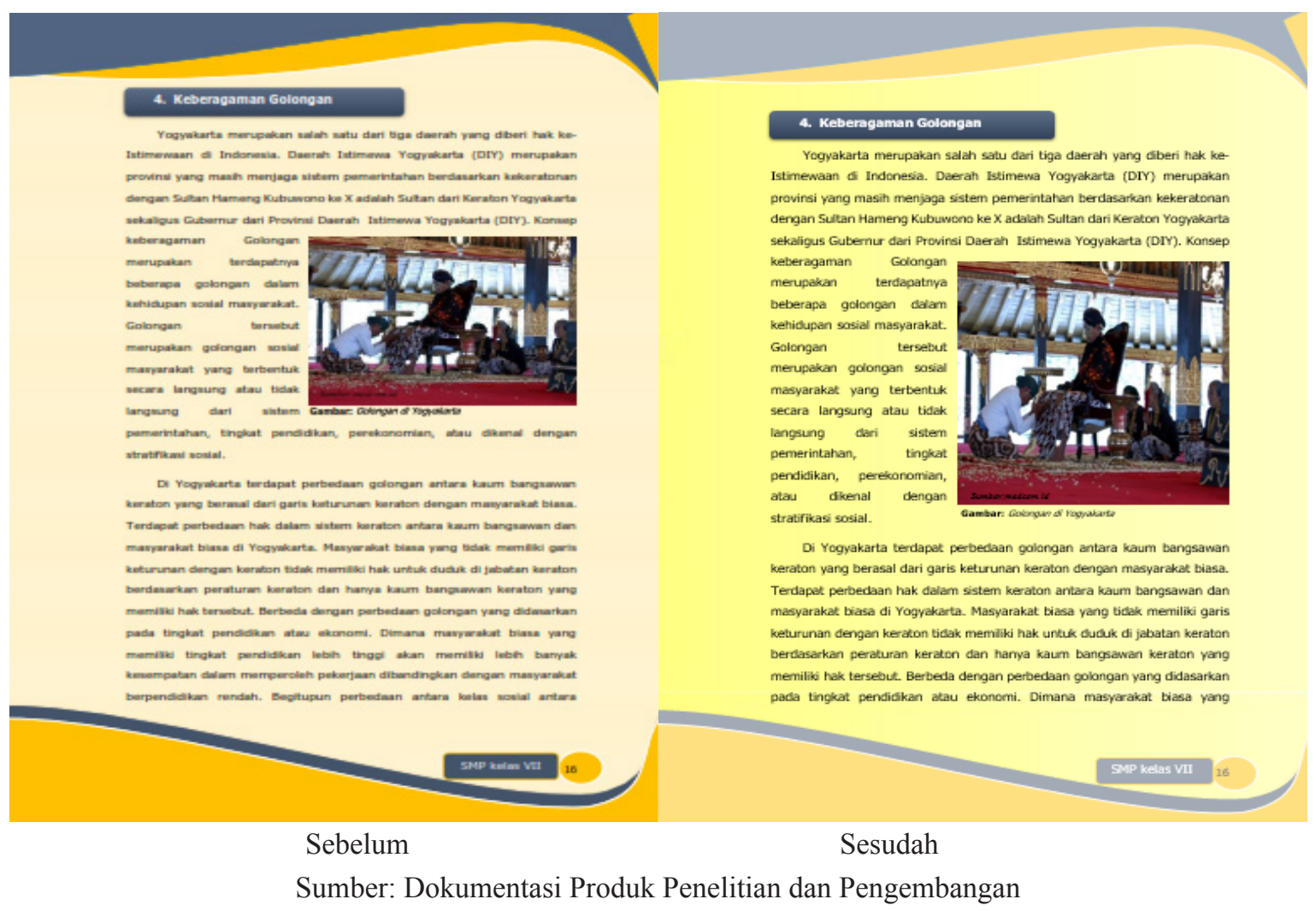

coba kedua (Small-Group Trial) menunjukkan bahwa produk yang dikembangkan berada pada interval sangat layak untuk digunakan dalam proses belajar mengajar karena dapat diterima dan dipahaminya dengan mudah oleh peserta didik. Berdasarkan lembar respons penilaian peserta didik membuktikan bahwa peserta didik lebih mudah mengerti materi keberagaman dengan menggunakan bahan ajar yang dikembangkan dibandingkan dengan penggunaan buku ajar biasa.

Hasil respons penilaian peserta didik tersebut menjadi indikator kelayakan produk bahan ajar yang dikembangkan terhadap pemahaman konsep keberagaman budaya setiap peserta didik. Berdasarkan penilaian produk oleh peserta didik, skor kelayakan produk penelitian dan pengembangan pada tahap small-group trial dapat disajikan pada tabel 12 .

Tabel 12

Skor Kelayakan Respons Peserta Didik

\begin{tabular}{|c|c|c|c|c|}
\hline Res. & (X) & $\begin{array}{l}\text { Rata- } \\
\text { rata }\end{array}$ & $\begin{array}{l}\text { Interval } \\
\text { Kategori }\end{array}$ & Kategori \\
\hline 1 & 32 & \multirow{10}{*}{33,5} & \multirow{10}{*}{$32,5<X \leq 40$} & \multirow{10}{*}{ Sangat Layak } \\
\hline 2 & 36 & & & \\
\hline 3 & 33 & & & \\
\hline 4 & 36 & & & \\
\hline 5 & 32 & & & \\
\hline 6 & 35 & & & \\
\hline 7 & 32 & & & \\
\hline 8 & 35 & & & \\
\hline 9 & 31 & & & \\
\hline 10 & 33 & & & \\
\hline
\end{tabular}

Sumber: Hasil Pengolahan Data

Sedangkan interval kelayakan produk pada small-group trial sebagai respons dari peserta didik dapat disajikan pada tabel 13.

Hasil tabulasi penilaian peserta didik terhadap kelayakan produk penelitian dan pengembangan dijadikan salah satu 
Ridwan Santoso, Wuri Wuryandani -- Pengembangan Bahan Ajar PPKn Berbasis Kearifan Lokal Guna Meningkatkan Ketahanan Budaya Melalui Pemahaman Konsep Keberagaman

Tabel 13

Interval Kelayakan Produk Pada Small-Group Trial Respons Peserta Didik

\begin{tabular}{ccr}
\hline Nilai & \multicolumn{1}{c}{$\begin{array}{c}\text { Interval respons peserta } \\
\text { didik }\end{array}$} & \multicolumn{1}{c}{ Kategori } \\
\hline A & $32,5<\mathrm{X} \leq 40$ & Sangat Layak \\
B & $25<\mathrm{X} \leq 32,5$ & Layak \\
C & $17,5<\mathrm{X} \leq 25$ & Kurang layak \\
D & $10<\mathrm{X} \leq 17$ & Tidak layak \\
\hline & \multicolumn{2}{c}{ Sumber: Hasil Pengolahan Data }
\end{tabular}

dasar penentuan kelayakan produk yang dikembangkan dalam usaha meningkatkan ketahanan budaya lokal Indonesia di tengah arus globalisasi melalui peningkatan pemahaman konsep keberagaman budaya peserta didik kelas VII. Hasil perhitungan kelayakan produk menggunakan rumus rata-rata pada gambar 1 diperoleh hasil sebesar 33,5. Hasil hitung rata-rata kelayakan produk dari lembar penilaian peserta didik di konversikan ke dalam interval kelayakan produk pada tabel 5. Skor tersebut diperoleh nilai A pada kategori sangat layak, karena nilai $\mathrm{X}$ empiris dari rata-rata penilaian peserta didik berada pada interval $32,5<\mathrm{X} \leq 40$.

Data kelayakan produk bahan ajar yang dikembangkan oleh peserta didik didukung dengan data kelayakan produk dari penilaian guru pada tahap small-group trial sebagai pengguna produk pengembangan. Hasil penilaian dari guru diperoleh data yang menunjukkan skor empiris kelayakan sebesar 63. Skor empiris (X) yang diperoleh berada di interval 55,25 $<\mathrm{X} \leq 68$ dengan nilai $A$ yang berarti ada kategori sangat layak untuk digunakan guru dalam proses belajar mengajar di sekolah.

Hasil uji coba tahap kedua (small-group trial) menjadi dasar pengambilan kesimpulan bahwa produk yang dikembangkan berupa bahan ajar PPKn berbasis kearifan lokal sangat layak untuk digunakan guru dan peserta didik dalam kegiatan belajar mengajar Pendidikan Pancasila dan Kewarganegaraan. Tujuannya untuk meningkatkan ketahanan budaya lokal terhadap ancaman terkikisnya budaya lokal di tengah arus globalisasi melalui peningkatan pemahaman konsep keberagaman budaya dari hasil proses pembelajaran di sekolah. Data hasil penilaian guru PPKn pada tahap smallgroup trial dapat disajikan pada tabel 14 .

Tabel 14

Data Penelitian Tahap Small-Group Trial

\begin{tabular}{lllll}
\hline No & Responden & Skor & Nilai & Kategori \\
\hline 1 & Guru PPKn & 63 & A & Sangat Layak \\
\hline
\end{tabular}

Sumber: Hasil Pengolahan Data

Sedangkan interval kelayakan produk menurut penilaian guru dapat ditunjukkan pada tabel 15 .

Tabel 15

Interval Kelayakan Respons Guru

\begin{tabular}{cclr}
\hline No & Nilai & $\begin{array}{c}\text { Interval Respons } \\
\text { Guru }\end{array}$ & \multicolumn{1}{c}{ Kategori } \\
\hline 1 & A & $55,25<\mathrm{X} \leq 68$ & Sangat Layak \\
2 & B & $42,5<\mathrm{X} \leq 55,25$ & Layak \\
3 & C & $29,75<\mathrm{X} \leq 42,5$ & Kurang layak \\
4 & D & $17<\mathrm{X} \leq 29,75$ & Tidak layak \\
\hline
\end{tabular}

Sumber: Hasil Pengolahan Data

Hasil pengujian kelayakan produk di tahap penilaian ahli (aspek materi dan aspek media), pengujian lapangan awal (One-to-One Trial), dan pengujian lapangan kedua (SmallGroup Trial) sesuai hasil penelitian Satriawan dan Rosmiati (2017) yang membuktikan proses belajar mengajar kontekstual dengan memanfaatkan nilai kearifan lokal berfungsi efektif meningkatkan pemahaman konsep materi ajar. Begitupun hasil penelitian Wahana (2015) membuktikan bahwa budaya sekolah dan budaya yang dimiliki generasi millennial berpengaruh signifikan terhadap ketahanan individu dalam kehidupan sosial budaya. 
Maka dari itu, produk yang dikembangkan memperoleh nilai kelayakan sangat layak dengan tujuan meningkatkan ketahanan budaya lokal melalui upaya meningkatkan pemahaman konsep keberagaman budaya.

Berdasarkan hasil analisis kelayakan produk pada penilaian ahli aspek (materi dan media), pengujian lapangan awal (One-to-One Trial), dan sampai pengujian kedua (SmallGroup Trial) membuktikan bahwa produk yang dikembangkan berupa sangat layak untuk dipergunakan pendidik dan peserta didik dalam kegiatan belajar mengajar. Hal itu didukung hasil penelitian Pornpimon, Wallapha, dan Prayuth (2014) yang merekomendasikan penggunaan nilai-nilai kearifan lokal di dalam proses kegiatan belajar mengajar di sekolah dengan didukung oleh lingkungan sekitar. Oleh karena itu, hasil pengembangan ini dapat menjadi pilihan bagi guru dan para praktisi pendidikan lain untuk menggunakan produk penelitian pengembangan berbasis kearifan lokal atau berinovasi mandiri mengembangkan sumber belajar inovatif dengan memanfaatkan kearifan lokal yang ada guna meningkatkan ketahanan budaya lokal daerah melalui peningkatan pemahaman konsep keberagaman budaya pada peserta didik.

\section{SIMPULAN}

Berdasar penjelasan tersebut di atas dapat ditarik simpulan sebagai berikut.

Pertama, bahan ajar yang dikembangkan merupakan bahan ajar kontekstual berdasarkan pada nilai-nilai kearifan lokal daerah dan disesuaikan dengan muatan materi dalam kurikulum 2013. Bahan ajar PPKn berbasis kearifan terbukti berada pada kategori sangat layak untuk dipergunakan di dalam proses belajar mengajar mata pelajaran Pendidikan Pancasila dan Kewarganegaraan. Maka dari itu, produk pengembangan berupa bahan ajar PPKn berbasis kearifan lokal terbukti dapat dipergunakan oleh guru dan peserta didik guna meningkatkan ketahanan budaya Indonesia melalui upaya peningkatan pemahaman konsep keberagaman budaya peserta didik.

Kedua, hasil dari pengembangan ini dapat menjadi referensi penelitian atau pengembangan selanjutnya untuk meneliti atau mengembangkan sumber belajar lain yang layak dipergunakan dalam proses kegiatan belajar mengajar di sekolah guna memudahkan guru dan peserta didik mencapai tujuan belajar pada aspek-aspek tujuan pembelajaran sesuai dengan kurikulum 2013 dan kebutuhan proses belajar mengajar di sekolah.

\section{DAFTAR PUSTAKA}

Akomolafe, C. O., dan V.O. Adesua, 2016, The Impact of Physical Facilities on Students' Level of Motivation and Academic Performance in Senior Secondary Schools in South West Nigeria. Journal of Education and Practice, Vol. 7, No. 4, hh. 38-42.

Andayani, A. A. I., E. Martono, dan M. Muhamad, 2017, Pemberdayaan masyarakat melalui pengembangan desa wisata dan implikasinya terhadap ketahanan sosial budaya wilayah (studi di desa wisata Penglipuran Bali). Jurnal Ketahanan Nasional, Vol. 23, No. 1, hh. 1-16.

Anikarnisia, N. M., dan I.Wilujeng, 2020, January. Need assessment of STEM education based based on local wisdom in junior high school. In Journal of Physics: Conference Series. Vol. 1440, No. 1, hh. 012-092). IOP Publishing.

Asmah, A., dan F.N. Mustaji, 2014, Pengaruh Pemanfaatan Lingkungan Alam Pasir 
Ridwan Santoso, Wuri Wuryandani -- Pengembangan Bahan Ajar PPKn Berbasis Kearifan Lokal Guna Meningkatkan Ketahanan Budaya Melalui Pemahaman Konsep Keberagaman

sebagai Sumber Belajar terhadap Kemampuan Sains dan Motorik Halus Anak Usia Dini. Kwangsan, Vol. 2, No. 1, hh. 13-36.

Badan Pusat Statistik, 2017, Angka partisipasi murni (apm) sekolah menengah pertama (smp) menurut jenis kelamin dan tipe daerah, Jakarta: Badan Pusat Statistik.

Baka, N. A., D.N.L.Laksana, dan K.D.Dhiu, 2019, Konten Dan Konteks Budaya Lokal Ngada Sebagai Bahan Ajar Tematik Di Sekolah Dasar. Journal of Education Technology, Vol. 2, No. 2, hh. 46-55.

Branch, M.R., 2009, Instructional design: The ADDIE approach, New York: Springer.

Crosby, S., K. Laird, dan S. Younie, 2019, Interactive health-hygiene education for early years: the creation and evaluation of learning resources to improve understanding of handwashing practice. International Journal of Early Years Education, Vol. 27, No. 4, hh. 374-390.

Davey, B., K.Elliott, dan M. Bora, 2019, Negotiating Pedagogical Challenges in the Shift from Face-to-Face to Fully Online Learning: A Case Study of Collaborative Design Solutions by Learning Designers and Subject Matter Experts. Journal of University Teaching and Learning Practice, Vol. 16, No. 1, hh. 1-22.

Dewi, N. W. B. S., M.R.Kristiantari, IGAO. Negara, dan S.P.M. Ke, 2014, Model tematik bernuansa kearifan lokal berbantuan media animasi berpengaruh terhadap hasil belajar IPA siswa kelas III SD Negeri gugus kapten japa. MIMBAR PGSD Undiksha, Vol. 2, No. 1.

Fischer, C., B. Fishman,C. Dede, A. Eisenkraft, K. Frumin, B. Foster, dan A. McCoy,
2018, Investigating relationships between school context, teacher professional development, teaching practices, and student achievement in response to a nationwide science reform. Teaching and Teacher Education, Vol. 72, hh. 107-121.

Fitiriasari, P. D., 2019, Partisipasi Masyarakat Dalam Kesenian Soreng Guna Meningkatkan Ketahanan Budaya (Studi Di Desa Banyusidi, Kecamatan Pakis, Kabupaten Magelang, Jawa Tengah). Jurnal Ketahanan Nasional. Vol. 25, No. 3, hh. 409-420.

Gershenson, S., 2016, Linking teacher quality, student attendance, and student achievement. Education Finance and Policy, Vol. 11, No. 2, hh. 125-149.

Hanushek, E. A., 2020, Education production functions. In The Economics of Education, hh. 161-170, Academic Press.

Hanushek, E. A., dan L. Woessmann, 2020, Education, knowledge capital, and economic growth. In The Economics of Education, hh. 171-182, Academic Press.

Jusuf, H., 2005, Improving Teacher Quality, a Keyword for Improving Education Facing Global Challenges. Turkish Online Journal of Educational TechnologyTOJET, Vol. 4, No. 1, hh. 33-37.

Lestari, G., A. Armawi, dan M.Muhamad, 2016, Partisipasi pemuda dalam mengembangkan pariwisata berbasis masyarakat untuk meningkatkan ketahanan sosial budaya wilayah (Studi di Desa Wisata Pentingsari, Umbulharjo, Cangkringan, Sleman, DI Yogyakarta). Jurnal Ketahanan Nasional, Vol. 22, No. 2, hh. 137-157. 
Mantri, Y. M., 2014, Peran Pemuda Dalam Pelestarian Seni Tradisional Benjang Guna Meningkatkan Ketahanan Budaya Daerah (Studi Di Kecamatan Ujungberung Kota Bandung Provinsi Jawa Barat). Jurnal Ketahanan Nasional, Vol. 20, No. 3, hh. 65-83.

Mulyasa, 2013, Pengembangan dan implementasi pemikiran kurikulum. Bandung: PT Rosdakarya.

Nasreen, M., Q.M.Janjua, dan S. Malik, 2018, Impact of contextual learning on retention of knowledge. Pakistan Journal of Physiology, Vol. 14, No. 2, hh. 43-45.

Nilasari, E., E.T. Djatmika, dan A. Santoso, 2016, Pengaruh penggunaan modul pembelajaran kontekstual terhadap hasil belajar siswa kelas V Sekolah Dasar. Jurnal Pendidikan: Teori, Penelitian, dan Pengembangan, Vol. 1, No. 7, hh. 1399-1404.

OECD, 2018, PISA 2018 Results combined executive summaries (Volume I,II, \& III): Excellence and Equity in Education, PISA, OECD, Vol. I, Paris.

Pangalila, T., B. Ngarawula, K. Sadhana, A.L. Lonto, dan S. Pasandaran, 2018, Local wisdom si tou timou tumou tou in forming tolerance of Tomohon city people of North Sulawesi. In $1 s t$ International Conference on Social Sciences (ICSS 2018), Atlantis Press.

Perwitasari, S., dan W.Wahjoedi, 2018, Pengembangan Bahan Ajar Tematik Berbasis Kontekstual. Jurnal Pendidikan: Teori, Penelitian, dan Pengembangan, Vol. 3, No. 3, hh. 278-285.

Pornpimon, C., A. Wallapha, dan C. Prayuth, 2014, Strategy challenges the local wisdom applications sustainability in schools. Procedia-Social and Behavioral Sciences, Vol. 112, hh. 626-634.

Rusman, 2010, Model model pembelajaran, Bandung: Rajawali Pers.

Satriani, I., E.Emilia, dan H.Gunawan, 2012, Contextual teaching and learning approach to teaching writing. Indonesian Journal of Applied Linguistics, Vol. 2, No. 1, hh. 10-22.

Satriawan, M., dan R.Rosmiati, 2017, Pengembangan bahan ajar fisika berbasis kontekstual dengan mengintegrasikan kearifan lokal untuk meningkatkan pemahaman konsep fisika pada mahasiswa. JPPS (Jurnal Penelitian Pendidikan Sains), Vol. 6, No. 1, hh. 1212-1217.

Shaikh, N., 2019, Use of Digital Technology in Education Its Impact on Academic Achievement of a Student. Journal of Global Economy, Vol. 15, No. 1, hh. 3743.

Strom, B., dan T.Falch, 2020, The role of teacher quality in education production. In The Economics of Education, hh. 307319, Academic Press.

Sugiyono, P. D., 2013, Metode penelitian manajemen. Bandung: Alfabeta, CV.

Sulisworo, D., 2016, The Contribution of the Education System Quality to Improve the Nation's Competitiveness of Indonesia. Journal of Education and Learning, Vol. 10, No. 2, hh. 127-138.

Suradiva, A. O., M. Muhammad, dan S. Saryani, 2018, Partisipasi Pemuda Dalam Berkembangnya Desa Wisata Guna Meningkatkan Ketahanan Sosial Budaya Masyarakat Desa (Studi di Desa Wisata Batubulan, Sukawati, Gianyar, Bali). Jurnal Ketahanan Nasional, Vol. 24, No. 3, hh. 389-402. 
Tavakoli, M., dan S. Baniasad-Azad, 2017, Teachers conceptions of effective teaching and their teaching practices: a mixed-method approach. Teachers and Teaching: Theory and Practice, Vol. 23, No. 6, hh. 674-688.

UNDP, 2018, Human development indices and indicators 2018. Statistical Update, h. 123.

Viswanath, K. M.D., S.Kusuma, dan S.K.Gupta, 2012, Cloud computing issues and benefits modern education. Global Journal of Computer Science and Technology. Vol. 2, No. 10, hh. 14-20.

Wahana, H. D., 2015, Pengaruh Nilai-Nilai Budaya Generasi Millennial Dan Budaya Sekolah Terhadap Ketahanan Individu (Studi Di SMA Negeri 39, Cijantung, Jakarta). Jurnal Ketahanan Nasional, Vol. 21, No. 1, hh. 14-22.

Widoyoko, E. P. S. 2009. Evaluasi program pembelajaran. Yogyakarta: Pustaka Pelajar.

Wijianto, W., 2019, Relevansi Sumber Belajar Ketahanan Nasional Mata Pelajaran Pendidikan Pancasila Dan Kewarganegaraan Dengan Indikator
Pencapaian Kompetensi Siswa. Jurnal Ketahanan Nasional, Vol. 25, No. 3, hh. 393-408.

Yeni, Y. R.,H. Syarifuddin, dan R. Ahmad, 2019, The effect of contextual teaching and learning approach and motivation of learning on the ability of understanding the mathematics concepts of grade $\mathrm{V}$ student. In IOP Conference Series: Earth and Environmental Science. Vol. 314, No. 1, hh. 012-064, IOP Publishing. Yudha, A., S.Sufianto, B.E.P. Damara, B. Taqwan, dan S. Haji, 2019, The Impact of Contextual Teaching and Learning (CTL) Ability in Understanding Mathematical Concepts. In International Conference on Educational Sciences and Teacher Profession (ICETeP 2018), Atlantis Press.

Zhang, W., dan Y.Sun, 2017, December 1. The Study on the Support of Online Learning Resource in Blended Learning Based on Learning Process. In 2017 International Conference of Educational Innovation through Technology (EITT), hh. 242243. IEEE. 